\title{
Artigos de resenha
}

\section{Coleção “Estudos Internacionais” da Editora da Universidade (UFRGS)}

SOUTO, Cíntia. A diplomacia do interesse nacional: a política externa do governo Médici. Porto Alegre: Editora da UFRGS, 2003.

SENNES, Ricardo. As mudanças da política externa brasileira nos anos 80: uma potência média recém industrializada. Porto Alegre: Editora da UFRGS, 2003.

PEREIRA, Analúcia. A política externa do governo Sarney: a nova república diante do reordenamento internacional (1985-1990). Porto Alegre: Editora da UFRGS, 2003.

Esses são os três primeiros títulos da coleção Estudos Internacionais, coordenada pelo Professor Paulo Fagundes Vizentini e editada pelo Núcleo de Estudos de Estratégia e Relações Internacionais (Nerint) do Instituto LatinoAmericano de Estudos Avançados da Universidade Federal do Rio Grande do Sul, em parceria com a Editora da Universidade/UFRGS. A coleção é destinada a divulgar estudos, teses, dissertações e seminários produzidos ou orientados pelos pesquisadores do núcleo, bem como textos relevantes na área de relações internacionais.

Embora trabalhando com temporalidades diferenciadas, de certa forma os três livros têm uma linha de continuidade, pois discutem a mesma matriz de inserção internacional, formulada nos anos 1970 no Brasil e que vigorou até o final da década de 1980, mais conhecida pelo seu ápice, o Pragmatismo Responsável do governo Geisel. Mas a estruturação dessa matriz já vinha ocorrendo no período do Governo Médici, assim como, embora o regime militar tenha formalmente acabado em 1985, seu modelo de inserção internacional duraria até 1990. Nesse sentido, esses autores trabalham com os seus primeiros ensaios (no Governo Médici) e sua crise (já no final do governo Sarney).

O trabalho de Cíntia Souto analisa as linhas de ruptura e continuidade do governo Médici. No primeiro capítulo, a autora discute o modelo político-econômico e concepção de diplomacia do interesse nacional no contexto do projeto de "Brasil Grande Potência”. No segundo capítulo, temos uma interessante discussão acerca do bilateralismo e do terceiro mundismo da diplomacia do Governo Médici, apontando como essas duas dimensões eram membros de uma mesma equação, que buscava a maximização de oportunidades de inserção internacional. 
No terceiro e quarto capítulos, a autora analisa as opções tomadas pelo Brasil no sistema internacional, destacando as relações conflituosas com os Estados Unidos, definido pela autora como um relacionamento especial, mas não subordinado. Em relação à América Latina, o Brasil lançou uma ofensiva comercial buscando ampliar mercados na região. A rivalidade com a Argentina na Bacia do Prata também foi uma constante. Já as relações extra-hemisféricas procuravam alternativas aos Estados Unidos (encontradas em parte na Europa Ocidental e Japão) e buscavam formas de cooperação com os países do Terceiro Mundo, como Oriente Médio e África Subsaariana.

Em síntese, a política externa de Médici, rejeitando a interdependência e o terceiro-mundismo reivindicatório, buscou conciliar o desenvolvimento nacional com o capitalismo internacional, do qual pretendia participar como um importante protagonista. Buscava no bilateralismo a forma de relacionamento com países com que tinha relações históricas e utilizava o terceiro-mundismo como bandeira para aproximação de novos parceiros. Numa posição típica de país intermediário, o Brasil estava lançando as bases para o pragmatismo responsável dos anos seguintes.

Já o livro de Ricardo Sennes trabalha com as mudanças na matriz da política externa brasileira na década de 1980 . No primeiro capítulo, o autor discute o conceito de Potência Média e de país recém-industrializado, concluindo a pertinência da inclusão do Brasil nessa categoria para compreender sua política externa. No segundo capítulo, o autor desenvolve a matriz da política externa brasileira no início da década de 1980 a partir das dimensões multilateral, bilateral e regional.

Para Sennes, as políticas externas conduzidas a partir de 1980 estiveram, até pelo menos 1987-1988, de forma geral apoiadas em uma mesma matriz, cujos principais elementos foram estabelecidos na década de 1970. As posturas multilaterais e bilaterais foram estabelecidas durante o governo Geisel (1974-1979) e as posturas regionais, marcadamente no governo Figueiredo (1979-1984). Dentre as características dessa matriz de inserção internacional do Brasil, podem-se enumerar: a noção de si próprio como Potência Intermediária; o alinhamento com o Terceiro Mundo; a intensa presença do Brasil nos órgãos multilaterais; a diversificação das relações com os países desenvolvidos, ampliando laços com Europa e Japão; e o projeto de aumentar a influência na América do Sul e aprofundar as relações com outras potências médias.

No terceiro e quarto capítulos, o autor analisa o desmoronamento das condições internas e internacionais que sustentavam a matriz de política externa dos anos 1970 e 1980, gerando um grande impacto na forma de inserção internacional. No quinto e último capítulo, o autor desenvolve em traços gerais a matriz emergente da política externa do Brasil no final dos anos 1980 e início dos anos 1990. As potências médias e recém-industrializadas (como o Brasil) 
processaram o deslocamento de uma postura antagônica para uma postura de participação e aceitação geral das bases do ordenamento internacional.

O governo José Sarney constitui um importante período para a análise das mudanças na matriz da política externa brasileira nos anos 1980, pois se situa entre duas fases bem definidas, a política externa do regime militar e a política externa neoliberal do governo Collor. Em seu trabalho, Analúcia Pereira parte da análise da política externa do regime militar para verificar que a diplomacia do governo José Sarney caracterizou-se por fortes traços de continuidade daquela efetuada anteriormente.

A autora discute a posição do Brasil no contexto internacional dos anos 1980, caracterizados pela retomada da ofensiva dos Estados Unidos nos cenários mundial e regional, pela crise do campo socialista, pelas dificuldades do diálogo Norte-Sul, pela crise da dívida externa e a pressão das economias desenvolvidas sobre os países mais pobres. Em um cenário internacional adverso, o governo Sarney procurou manter o eixo de inserção diplomática patrocinado nos governos Geisel e Figueiredo.

Em seguida, o livro trata das relações hemisféricas e extra-hemisféricas. Nas relações hemisféricas, cabe lembrar as relações conflituosas com os Estados Unidos e a aproximação com os países da Bacia do Prata, em especial a Argentina, que culminará com os tratados de integração na região. Nas relações extrahemisféricas, houve dificuldades e avanços. Como contrapartida a um certo distanciamento da Europa Ocidental, o Brasil aprofundou relações com os países do campo socialista e os países do Sul. Embora a política externa de Sarney tenha traços de continuidade com o regime militar, ocorreram saltos qualitativos em direção aos países do Terceiro Mundo e do Cone Sul.

Assim, esses três estudos abordam a matriz de inserção internacional dos anos 1970 e 1980 em suas diferentes fases e com características próprias, mas marcadas pela crescente perda de complementaridade econômica e distanciamento político dos Estados Unidos, busca de novos parceiros internacionais e multilateralização da diplomacia. Num contexto de redefinição da política externa brasileira promovida pelo Governo Federal em 2003, esses trabalhos oportunizam o importante debate acerca dessas experiências diplomáticas. A reflexão sobre seus avanços, vicissitudes e contradições, certamente, contribuirá para o debate sobre uma nova inserção internacional do Brasil.

Esses são os três primeiros trabalhos publicados nessa coleção. Ainda para este ano estão previstos a publicação da obra de Paulo França, sobre a "Guerra de Kosovo e o conceito de intervenção Humanitária" (defendida no Curso de Altos Estudos do Itamaraty), e a da professora argentina Miryam Colacrai sobre “o Ártico, a Antártica e as Relações Internacionais". As obras podem ser adquiridas por meio do e-mail editora@ufrgs.br. 